\title{
VIOLENCE AS A KEY MANIFESTATION OF SOCIAL PROBLEMS IN BOSNIA AND HERZEGOVINA*
}

\author{
B.Č. Milošević Šošo \\ University of East Sarajevo \\ Alekse Šantića St., 1, Pale, 71000, Republic of Srpska, \\ Bosnia and Herzegovina \\ (e-mail: milosevic_biljana@yahoo.com)
}

\begin{abstract}
The term 'social problem' was first introduced as a synonym for 'illnesses' under unfavorable social-economic conditions [9]. Social problems are considered by social science when it comes to their negative consequences for satisfying one's needs and self-realization [15]. According to R. Metron and R. Nisbet, social problems are "the result of mismatch between social values and reality; the effect of social causes that are considered unfavorable; they can be manifest and latent; they have social consequences and determine planned and meaningful social actions" [10. P. 156]. The article focuses on the social problems in a part of Bosnia and Herzegovina $(\mathrm{B} \& \mathrm{H})$ - the Republic of Srpska - to prevent and minimize them even in their most sociopathic forms. The empirical study was conducted on the sample of 220 respondents (105 male and 113 female) from October 2016 to January 2017 in seven municipalities of the Republic of Srpska as a part of B\&H. The author wanted to estimate the respondents' awareness of certain notions related to the pathological sexual assaults (paraphilias) and on the level of domestic violence in particular against women. The study combined empirical and theoretical parts to test the authors' hypotheses. Among them an assumption that many respondents do not know the meaning and are not in any other ways familiar with different types of paraphilias. Another author's assumption was that women of the Republic of Srpska are more exposed to specific types of violence, which is still not enough discussed in public due to the traditional communicative and social barriers. The third author's hypothesis was that women are more exposed to psychological and physical violence due to unfavorable social-economic conditions. To prove this the author used statistical data to assess the relationship of different features of the sample and reveal the factors affecting the development and changes in the above mentioned social problems. If the factors considered in the article are not publicly recognized and discussed the current situation will lead to the highly deviant (delinquent) behaviour that will turn into a socially acceptable model and determine serious negative consequences for the society.
\end{abstract}

Key words: social problem; violence; paraphilia; domestic violence; survey; the Republic of Srpska

\section{THEORETICAL FRAMEWORK AND METHODOLOGY OF THE RESEARCH}

The article presents both an empirical study and a theoretical research or even a theoretical revision based on the relevant empirical facts. Such a revision focusing on theoretical premises, conceptions, and ideas is impossible without a critical approach to the problem under study regarding the ways of its traditional conceptualization for it affects the empirical techniques. The research combines different theoretical finding of Durkheim, Merton, and Parsons, and of some authors from the Balkans such as Milosavljević, Bošković, Jugović, Ljubičić, and others. The hypotheses of the research are based on the argument that the deviant behavior in today's society is rather frequent

* C B. C. Milošević Šošo, 2018. 
primarily due to prevalence of illegitimate modes and/or means to satisfy individual and group needs, while the degree of satisfaction of needs in our society depends on the quality of interaction of factors affecting socialization. Furthermore, it was necessary to apply the quantitative methodology to estimate the scale of the problem and measure the relationship of its different aspects and factors [5. P. 134].

The most general part of the survey refers to the social-demographic and socialeconomic characteristics of respondents (sex, age, education, employment, structure of family, marital status, place of residence, financial situation, membership in political parties, employment status). Another part of the questionnaire refers to the respondents perception of deviant behavior (corruption, delinquent actions, violence) and to their own deviant practices and being victims of such (in various criminal acts, in domestic violence, cyber violence), to their understanding of friendship, their value orientations in everyday life, and so on.

The sample consisted of 220 respondents aged from 18 to 66 and over, 105 males and 113 females. The survey was conducted from October 2016 to January 2017 in seven municipalities of the Republic of Srpska (East Sarajevo, Banja Luka, Trebinje, Pale, Šekovići, Rogatica and Doboj). Most respondents were aged 18-24 (28,6\%) and 32-38 (18,6\%); were from Banja Luka (31\%), East Sarajevo (18,2\%) or Pale $(13,6 \%)$; live in towns $(62,3 \%)$; finished high school $(58,6 \%)$ or have a university degree $(22,3 \%)$ (Table 1$)$.

Table 1

\begin{tabular}{|c|c|c|c|}
\hline \multicolumn{2}{|c|}{ Characteristics } & Number & $\%$ \\
\hline \multirow[t]{4}{*}{ Sex } & Male & 105 & 47 \\
\hline & Female & 113 & 51,4 \\
\hline & No answer & 2 & 1 \\
\hline & Total & 220 & 100 \\
\hline \multirow{9}{*}{ Age } & $18-24$ & 63 & 28,6 \\
\hline & $25-31$ & 36 & 16,4 \\
\hline & $32-38$ & 41 & 18,6 \\
\hline & $39-45$ & 24 & 10,9 \\
\hline & $46-52$ & 26 & 11,8 \\
\hline & $53-59$ & 15 & 6,8 \\
\hline & $60-66$ & 4 & 1,8 \\
\hline & $66+$ & 11 & 5 \\
\hline & Total & 220 & 100 \\
\hline \multirow[t]{8}{*}{ Place of residence } & East Sarajevo & 40 & 18,2 \\
\hline & Banja Luka & 70 & 31 \\
\hline & Doboj & 20 & 9,1 \\
\hline & Pale & 30 & 13,6 \\
\hline & Trebinje & 20 & 9,1 \\
\hline & Rogatica & 20 & 9,1 \\
\hline & Šekovići & 20 & 9,1 \\
\hline & Total & 220 & 100 \\
\hline \multirow[t]{5}{*}{ Type of residence } & Urban area & 137 & 62,3 \\
\hline & Suburban area & 51 & 23,2 \\
\hline & Rural area & 31 & 14,1 \\
\hline & No answer & 1 & 0,5 \\
\hline & Total & 220 & 100 \\
\hline \multirow[t]{7}{*}{ Education } & Without elementary school & 3 & 1,4 \\
\hline & Elementary school & 6 & 2,7 \\
\hline & High school & 129 & 58,6 \\
\hline & Higher school & 26 & 11,8 \\
\hline & Academic degree & 49 & 22,3 \\
\hline & MBA degree or doctorate & 7 & 3,2 \\
\hline & Total & 220 & 100 \\
\hline
\end{tabular}


More than a half of the sample are unemployed $(59,1 \%)$, in particular students $(22,3 \%)$. Considering the period of their unemployment, most are unemployed for $1-3$ years $(8,2 \%), 4-7$ years $(9,1 \%), 8-11$ years $(5,5 \%)$ or for more than 12 years $(7,3 \%)$. The most frequent reasons for unemployment are as follows: fired as an unnecessary employee $(5,9 \%)$; the employer closed the company $(6,4 \%)$; got fired $(3,6 \%)$; never had a chance to be employed (27,3\%). Among the unemployed $27,7 \%$ are registered at the Bureau of Employment. Among the $40 \%$ employed 17,3\% work in the public sector, while $21,8 \%$ - in private sector. Usually, the respondents have their own apartments or houses $(39,5 \%)$ mainly owned by their parents $(47,3 \%) .42,3 \%$ are married, $45,5 \%$ - not married. As a rule, the respondents live in a family of four members (35,5\%), 26,9\% - a family of five and more members (Table 2).

Table 2

Social-economic characteristics of the sample

\begin{tabular}{|c|c|c|c|}
\hline \multicolumn{2}{|c|}{ Characteristics of the surveyors } & Number & $\%$ \\
\hline \multirow[t]{4}{*}{ Working status } & Employed & 88 & 40 \\
\hline & Unemployed & 130 & 59,1 \\
\hline & No answer & 2 & 1 \\
\hline & Total & 220 & 100 \\
\hline \multirow[t]{7}{*}{ Status of the unemployed } & Pupil & 1 & 5 \\
\hline & Student & 51 & 22,3 \\
\hline & Housewife & 25 & 11,4 \\
\hline & Pensioner & 12 & 5,5 \\
\hline & Looking for employment & 44 & 15 \\
\hline & No answer & 87 & 39,4 \\
\hline & Total & 220 & 100 \\
\hline \multirow[t]{6}{*}{ Unemployment period } & $1-3$ years & 18 & 8,2 \\
\hline & $4-7$ years & 20 & 9,1 \\
\hline & $8-11$ years & 12 & 5,5 \\
\hline & 12 years and more & 16 & 7,3 \\
\hline & No answer & 154 & 70 \\
\hline & Total & 220 & 100 \\
\hline \multirow[t]{10}{*}{ Reasons of unemployment } & Fired as unnecessary employee & 13 & 5,9 \\
\hline & The employer closed the company & 14 & 6,4 \\
\hline & Got fired & 8 & 3,6 \\
\hline & Wanted to find another job & 3 & 1,4 \\
\hline & Illness or injury & 3 & 1,4 \\
\hline & You felt too old to work & 3 & 1,4 \\
\hline & Have never been employed & 60 & 27,3 \\
\hline & $\begin{array}{l}\text { Have never looked for a job } \\
\text { because a partner does not allow to }\end{array}$ & 1 & 0,5 \\
\hline & No answer & 120 & 52,3 \\
\hline & Total & 220 & 100 \\
\hline \multirow{4}{*}{$\begin{array}{l}\text { The unemployed registered } \\
\text { at the Bureau of Employment }\end{array}$} & Yes & 61 & 27,7 \\
\hline & No & 97 & 44,1 \\
\hline & No answer & 62 & 28,2 \\
\hline & Total & 220 & 100 \\
\hline \multirow[t]{5}{*}{ The type of employment } & Private/public & 38 & 17,3 \\
\hline & Miscellaneous & 3 & 1,4 \\
\hline & Private & 48 & 21,8 \\
\hline & No answer & 131 & 59,5 \\
\hline & Total & 220 & 100 \\
\hline \multirow[t]{7}{*}{ Marital status } & Married & 94 & 42,3 \\
\hline & Unmarried & 100 & 45,5 \\
\hline & Divorced & 10 & 4,5 \\
\hline & Widower/widow & 10 & 4,5 \\
\hline & Extramarital cohabitation & 5 & 2,4 \\
\hline & No answer & 1 & 0,5 \\
\hline & Total & 220 & 100 \\
\hline
\end{tabular}


Continuation of table 2

\begin{tabular}{|l|l|r|c|}
\hline \multicolumn{2}{|c|}{ Characteristics of the surveyors } & Number & $\%$ \\
\hline \multirow{4}{*}{ Number of family members } & Three & 74 & 3,6 \\
\cline { 2 - 4 } & Four & 78 & 35,5 \\
\cline { 2 - 4 } & Five & 34 & 15,5 \\
\cline { 2 - 4 } & Six or more & 25 & 11,4 \\
\cline { 2 - 4 } & No answer & 9 & 4,1 \\
\cline { 2 - 4 } & Total & $\mathbf{2 2 0}$ & $\mathbf{1 0 0}$ \\
\hline Place of living & Personal ownership & 87 & 39,5 \\
\cline { 2 - 4 } & Parental ownership & 104 & 47,3 \\
\cline { 2 - 4 } & Tenant & 25 & 11,4 \\
\cline { 2 - 4 } & No answer & $\mathbf{2 2 0}$ & $\mathbf{1 0 0}$ \\
\cline { 2 - 3 } & Total & & 1,9 \\
\hline
\end{tabular}

\section{THE RESULTS OF THE SURVEY}

Social problems are usually defined as phenomena perceived by the majority of population as a cause-and-effect relationship being problematic and demanding a systematic prevention [15. P. 377]. According to Merton and Nisbet's typology of social problems, the research focused on the phenomena recognized as social problems in the Republic of Srpska. Further, the results of the survey are divided into thematic parts relevant to the aims of the research such as the awareness of the specific paraphilias, and whether the respondents have been victims of any types of domestic violence. Paraphilias have "incriminatory characteristics for they deal with misdemeanors, sometimes even with felonies" [4. P. 200]. Paraphilias refer to "any sort of aberrant sexual behavior that is preferred over the heterosexual, and that deviates from the culturally acceptable norms, while the quality or object of the sexual instinct is abnormal" [11. P. 117]. Social pathology within this type of deviant behavior consists of sexual inversions (pedophilia, geronthophilia, necrophilia and zoophilia) and sexual perversions (sadism, masohism, exibitionism, fetishism, transvestismand voyerism) [4], though the Diagnostic and Statistical Manual of Mental Disorders by the American Psychiatric Association (2000) distinguishes paraphilias and sexual dysfunctions. The survey aimed to find out whether the respondents were familiar with the notions referring to some sorts of paraphilia such as exhibitionism, voyeurism, fetishism, phone scatology, necrophilia, mammophilia, zoophilia, gerontology, and cleptophilia.

Thus, the types of paraphilia ${ }^{1}$ the respondents are familiar with include exibitionism $(68,6 \%)$, voyeurism $(60,5 \%)$, fetishism $(69,5 \%)$, and necrophilia $(51,4 \%)$; while other

${ }^{1}$ Exhibitionism refers to the exposition of one's body, especially private parts, with the purpose of attracting sexually and achieving sexual arousal; voyeurism - the attempt to sexually arouse while watching unknown person or a person who is undressing while unaware of being watched; fetishism - the situation when the erotic enjoyment is found in an inanimate object (fetish) or some other part of other's body; phone scatology — behavior that occurred in the era of electronic communication and is manifested in the satisfaction of sexual needs in harassment of unknown people through indecent phone calls; necrophilia refers to the sexual arousal in a contact with the dead and the inclusion in sexual activities with corpses; mammophilia refers to the sexual appeal to female breasts; zoophilia - sexual satisfaction achieved through copulation with animals; gerontophilia refers to sexual attraction to elder people; cleptophilia - sexual arousal found in stealing; infantophilia refers to sexual attraction to infants at the age of five or younger [11]. 
types of paraphilia mentioned in the questionnaire were rather unknown for most respondents especially phone scatology, necrophilia, mammophilia, gerontology, and infantophilia (Table 3).

Table 3

Understanding the meanings of the terms related to certain types of paraphilia

\begin{tabular}{|l|c|c|c|c|c|c|}
\hline \multirow{2}{*}{ Type } & \multicolumn{3}{|c|}{ Yes } & \multicolumn{2}{c|}{ No } & \multicolumn{2}{c|}{ I do not know } \\
\cline { 2 - 7 } & Number & $\%$ & Number & $\%$ & Number & \multirow{2}{*}{$\%$} \\
\hline Exhibitionism & 151 & 68,6 & 35 & 15,9 & 32 & 14,5 \\
\hline Voyeurism & 133 & 60,5 & 50 & 22,7 & 36 & 16,4 \\
\hline Fetishism & 153 & 69,5 & 36 & 16,4 & 30 & 13,6 \\
\hline Telephone Scatology & 52 & 23,6 & 114 & 51,4 & 52 & 23,6 \\
\hline Necrophilia & 113 & 51,4 & 72 & 32,7 & 33 & 15 \\
\hline Mammophilia & 71 & 32,3 & 101 & 45,9 & 45 & 20,5 \\
\hline Zoophilia & 119 & 54,1 & 60 & 27,3 & 39 & 17,7 \\
\hline Gerontophilia & 67 & 30,5 & 101 & 45,9 & 50 & 22,7 \\
\hline Cleptophilia & 123 & 55,9 & 59 & 26,8 & 35 & 15,9 \\
\hline Infantophilia & 52 & 23,6 & 110 & 50 & 56 & 25,5 \\
\hline
\end{tabular}

All the above mentioned types of paraphilia are characterized with aggression, while some of them, like fetishism, imply criminal activities and consequences ("acrotomophilia - a strong sexual interest in amputees; asphyxiophilia — sexual arousal by oxygen deprivation", and so on) [4. P. 213]. There is an interdependence between the way a society treats deviant behavior and the social perception of it. The public opinion on paraphilias of now well-known and frequent types relies on personal experience and judgment or on "jibbing, mocking, and isolation" [15]. In general society prefers to apply violence as a kind of problem solving in such cases for "aggression is a social reaction to the interests, attitudes, aims or values of certain individuals, social groups or societies that are tried to be forcefully changed" [15. P. 224].

From the sociological perspective, there are several interpretations of aggression: positivism, functionalism and Marxism, and several typologies of this deviation such as collective and individual aggression. According to Milosavljević [15], collective aggressions usually occur on the macro-level, i.e. on the level of global societies, social classes or large groups, while individual aggressions occur on the micro-level in the form of conflicts between individuals and small groups. Every type of aggression has certain social consequences, but this paper focuses on the micro-level - conflicts in families and domestic violence. Psychology prefers the term 'family climate', or emotional climate, manifested in family expressiveness (emotional exchange, how family members exchange emotions and communicate on the emotional level), family cohesion (whether or not family members are devoted to each another and the family as a whole), and conflicts (expressions of aggression and anger) [14].

Table 4 presents the distribution of conflicts in the respondents' families. In most cases, these are fights between parents and their children $(43,6 \%)$ and spouses $(40 \%)$. 
Fights in the family

\begin{tabular}{|c|c|c|c|c|c|c|c|}
\hline \multicolumn{2}{|c|}{ Between spouses } & \multicolumn{2}{c|}{$\begin{array}{c}\text { Between parents } \\
\text { and children }\end{array}$} & \multicolumn{2}{c|}{$\begin{array}{r}\text { Between parents } \\
\text { and their parents }\end{array}$} & \multicolumn{2}{c|}{ No answer } \\
\hline Number & $\%$ & Number & $\%$ & Number & $\%$ & Number & $\%$ \\
\hline 88 & 40 & 96 & 43,6 & 16 & 7,3 & 20 & 9,1 \\
\hline
\end{tabular}

Table 5 presents the quality of relations between family members, i.e. sorts of emotional communication that refer to aggression: $15 \%$ said that their family members sometimes hit one another; when someone complains about something, $42,3 \%$ of family members get upset; in $20,9 \%$ of families members often argue.

Table 5

Relationship in families

\begin{tabular}{|l|c|c|c|c|c|c|}
\hline \multirow{2}{*}{$\begin{array}{l}\text { Modes of family expressiveness } \\
\text { and emotional communication }\end{array}$} & \multicolumn{2}{|c|}{ Yes } & \multicolumn{3}{c|}{ No } & \multicolumn{2}{c|}{ No answer } \\
\cline { 2 - 7 } & Number & $\%$ & Number & $\%$ & Number & $\%$ \\
\hline Family members help each other & 200 & 90,9 & 12 & 5,5 & 8 & 3,6 \\
\hline Family members restrain feelings & 90 & 40,9 & 122 & 55,5 & 8 & 3,6 \\
\hline We say all we want at home & 167 & 75,9 & 43 & 19,5 & 10 & 4,5 \\
\hline $\begin{array}{l}\text { We are angry and we throw things } \\
\text { during quarrels }\end{array}$ & 44 & 20 & 167 & 75,9 & 9 & 4,1 \\
\hline $\begin{array}{l}\text { Family members often criticize } \\
\text { each another }\end{array}$ & 103 & 46,8 & 108 & 49,1 & 9 & 4,1 \\
\hline $\begin{array}{l}\text { Family members sometimes } \\
\text { hit another }\end{array}$ & 33 & 15 & 179 & 81,4 & 8 & 3,6 \\
\hline When we disagree, we try to stay calm & 176 & 80 & 36 & 16,4 & 8 & 3,6 \\
\hline $\begin{array}{l}\text { We believe that shouting is not } \\
\text { an option }\end{array}$ & 154 & 70 & 58 & 26,4 & 8 & 3,6 \\
\hline $\begin{array}{l}\text { Family members support } \\
\text { each another }\end{array}$ & 192 & 87,3 & 20 & 9,1 & 8 & 3,6 \\
\hline If you complain, someone gets upset & 93 & 42,3 & 119 & 54,1 & 8 & 3,6 \\
\hline $\begin{array}{l}\text { There is a feeling of togetherness } \\
\text { in the family }\end{array}$ & 190 & 86,4 & 22 & 10 & 8 & 3,6 \\
\hline $\begin{array}{l}\text { Family members almost never lose } \\
\text { temper }\end{array}$ & 96 & 44,5 & 114 & 51,8 & 8 & 3,6 \\
\hline We argue a lot & 46 & 20,9 & 166 & 55,5 & 8 & 3,6 \\
\hline
\end{tabular}

Table 6 shows the share of respondents being a victim of some types of violence. Usually this is psychological harassment $(23,3 \%)$, less often - physical violence $(14,4 \%)$, economic and cyber violence.

Table 6

Types of domestic violence and their scale

\begin{tabular}{|l|c|c|c|c|c|c|c|c|}
\hline \multirow{2}{*}{ Types } & \multicolumn{2}{c|}{ Never } & \multicolumn{2}{c|}{ Sometimes } & \multicolumn{2}{c|}{ Frequently } & \multicolumn{2}{c|}{ Very frequently } \\
\cline { 2 - 10 } & Number & $\%$ & Number & $\%$ & Number & $\%$ & Number & $\%$ \\
\hline Physical abuse & 180 & 81,8 & 31 & 14,4 & 6 & 2,7 & 0 & 0 \\
\hline Sexual harassment & 215 & 97,7 & 1 & 0,5 & 1 & 0,5 & 0 & 0 \\
\hline $\begin{array}{l}\text { Psychological } \\
\text { harassment }\end{array}$ & 161 & 73,2 & 51 & 23,2 & 4 & 1,8 & 1 & 0,5 \\
\hline Economic violence & 187 & 85 & 23 & 10,5 & 6 & 2,7 & 0 & 0 \\
\hline Cyber violence & 202 & 91,8 & 10 & 4,5 & 4 & 1,8 & 1 & 0,5 \\
\hline
\end{tabular}


The correlation between the phenomena under study was also estimated (Table 7). The results show that there is a statistically significant correlation between family fights and physical abuse (Pearson's coefficient of positive correlation $r=0,336$ ). Thus, the hypothesis that the families, in which members often fight, are prone to physical abuse (it implies the use of physical force or objects that cause pain, injury, and endanger health or life; in most cases it is manifested in hitting with hands, tearing hair, twisting body parts or face, hitting with different objects, deprivation of food, clothes or shoes, exposure to harsh climate conditions, and so on [15]) was confirmed.

Table 7

Correlation between family fights and some other types of violence

\begin{tabular}{|l|c|c|}
\hline \multicolumn{1}{|c|}{ Types of violence } & $r$ & $p$ \\
\hline Physical abuse & 0,336 & 0,000 \\
\hline Psychological harassment & 0,297 & 0,000 \\
\hline Economic violence & 0,267 & 0,000 \\
\hline
\end{tabular}

The same applies to other types of violence - both psychological and economic. Psychological violence threatens psychological integrity and health (humiliation, insults, verbal abuse, threats, ignorance, various restrictions on freedom), and is the most frequent type of domestic violence usually not implying physical abuse [1. P. 19]. However, there are many threats of physical abuse such as beating, breaking bones and a nose, smashing the teeth, pulling one's hair and setting it afire. Women are very often threatened by sexual abuse, while children are often manipulated. "Psychological harassment should be defined as spiritual but at the same time it implied destruction of cultural and religious beliefs, mocking, humiliation, ban to practice one's rituals, or coercion to acquire another value system" [1. P. 19]. According to Table 7, there is a correlation between "we argue a lot in the family" and being a victim of psychological harassment (positive coefficient of correlation $r=0,297$ ).

Economic violence refers to the control of economic resources and denial to provide such to satisfy women's needs, usually this is a denial to give women an opportunity to earn money. The victims of economic violence are given limited access to money in the household, deprived of personal needs and not able to have their own money, because other family member(s), who earn money, spend it on their own needs and leave the household without financial support [1. P. 18]. According to Table 7, there is a statistically significant correlation between family fights and economic violence (Pearson's coefficient of positive correlation $r=0,267$ ). Thus, the hypothesis that the families, in which members often fight, are prone to economic violence was confirmed.

Table 8 revelas possible factors of violence agains women (according to the UN Declaration on the Elimination of Violence against Women signed in 1993, violence against women is defined as every act of gender based violence that leads, or can lead to physical, psychic, sexual injury or suffering of the woman, including the threat to do so as such act, coercion or arbitrary deprivation of liberty, regardles if it takes place in public or private life). These factors include specific features of the family, economic possibilities, position in society, and some social-cultural factors. Alcohol addiction, drugs and gambling are the most evident possible factors of violence agains women. 
The respondents believe that alcohol addiction of the partner in $84,5 \%$ cases can lead to violence, drug addicion — in $85,9 \%$ cases, and gambling — in $75 \%$ cases; and distrust - in $80 \%$ cases.

Alcoholism is in fact a sociopathological problem that should be considered rather family than individual issue [4. P. 96]. Families of alcohol addicts encounter a series of problems that "affect the functionality of the family, change the quality of communication and emotional relations, threaten the psychological health of children and other family members" [7. P. 80]. Alcohol addicts' families are disfunctional in terms of relationships, which leads to social isolation, break of social contacts with family friends, aggression and disorder in family structure [4. P. 96]. Communictaion problems in such families prevent exchange of information for making important decisions, and the wives of alcoholics suffer anxious and depressive dissorders, are socialy isolated, think about suicide and try to commit it [7. P. 81]. Drugs determine violence against women for some drugs can temporarily provoke physical violence, and abstinential periods imply aggressive outbursts. The relationship of drugs and violence form three types of deviant behavior: systematic, economic-compulsive and psychopharmacological [4. P. 145]. The problems families face when one of the partners is a drug addict are similar to the families of alcoholics: disorder in social relations, inability to adapt in family relations, and tendency to isolationism. Such families are like an isolated island for the communication between family members is weakened, the education of children is neglected, and traditional moral values are ignored [6. P. 19]. Gambling addiction of a partner can also lead to violence because the main feature of gambling is that the game fiction becomes reality [15. P. 218]. The main goal of gambling is acquisition of material goods accompanied with a certain dose of joy; gambling as a form of behavior means that the person is ready to loose rather than to win, which makes the gamlers's family gambling victims.

Table 8

Potential factors of violence against women

\begin{tabular}{|l|c|c|c|c|c|c|}
\hline \multirow{2}{*}{ Factors } & \multicolumn{2}{c|}{ Yes } & \multicolumn{2}{c|}{ No } & \multicolumn{2}{c|}{ No answer } \\
\cline { 2 - 7 } & Number & $\%$ & Number & $\%$ & Number & $\%$ \\
\hline Spatial position of the household & 42 & 19,1 & 160 & 71,7 & 18 & 8,2 \\
\hline Economical position of the woman & 105 & 47,7 & 100 & 45,5 & 15 & 6,8 \\
\hline Material deprivation & 113 & 51,4 & 36 & 16,4 & 16 & 7,3 \\
\hline Frequent disagreements & 173 & 53,2 & 36 & 16,4 & 11 & 5 \\
\hline Low education & 118 & 53,6 & 88 & 40 & 14 & 6,4 \\
\hline Partiarhical family & 117 & 53,2 & 86 & 39,1 & 17 & 7,7 \\
\hline Former experience in marriage & 86 & 39,1 & 120 & 54,5 & 14 & 6,4 \\
\hline Distrust & 177 & 80,5 & 33 & 15 & 10 & 4,5 \\
\hline Alcohol addiction & 186 & 84,5 & 26 & 11,8 & 8 & 3,6 \\
\hline Drug addiction & 189 & 85,9 & 24 & 10,9 & 7 & 3,2 \\
\hline Gambling & 165 & 75 & 42 & 19,1 & 13 & 5,9 \\
\hline Participation in the wars & 104 & 47,3 & 99 & 45 & 17 & 7,7 \\
in the 1990s & & & & & & 6,8 \\
\hline Children's behavior & 80 & 36,4 & 125 & 56,8 & 15 & 7,7 \\
\hline Disability of the woman & 45 & 20,5 & 158 & 71,8 & 17 & 7,7 \\
\hline Illness of the woman & 45 & 20,5 & 158 & 71,8 & 17 & 7,7 \\
\hline Distribution of housework & 40 & 18,2 & 163 & 74,1 & 17 & 7 \\
\hline
\end{tabular}


According to Milosavljević [15], violence, physical injuries, even murders are often determined by family and gender relations because there are no mechanisms to resolve conflicts in such small social groups in close spatial and emotional contact. The research conducted in 2013 by the Agency for Gender Equality of B\&H and gender centers of its subjects in cooperation with statistical institutions and with the support of UNFPA and UN WOMEN (the representative sample consisted of 3300 women aged 18 and over) showed that $42,7 \%$ of women were victims of violence since they were 15 years old, and 52,8\% did not report any forms of violence; in 2013, 37,9\% of women were abused by partners, $14,1 \%$ - by other relatives and household members, and $15,3 \%$ - by partners, family, and community.

Society has always been interested in sociopathological problems, and men have always tried to suppress 'other' forms of behavior differing from a socially acceptable model. In ancient times, Platon advocated the principle of individualization trying to reveal and explain factors of certain crimes; Aristotle, on the contrary, emphasized socialcultural factors, while the representatives of Roman antiquity, Cicero and Seneca, underlined the purposefulness to punish the offenders. In the Dark Ages, the religion was absolutely dominant, and all good and bad actions were interpreted through ecclesiastical canons. The Age of Enlighment developed a more flexible approach to punishing deviant forms of behavior, for instance, Hobbes and Lock justified the purposefulness of punishments to ensure social peace. Positivism in social sciences first focused on social factors as key determinants of crime behavior. Representatives of other theories of positivism, such as Lombroso, believed in biological factors as determinants of crimes and some other deviations [4].

All approaches to the study of sociopathological problems admitted the importance of social and cultural enviroment for shaping individual and group behavior through socialization. Cultural isolation, deprivation, and subgroup values negatively affect individuals leading to socially unacceptable behaviors [8]. The consequences of unsuccessfull socialization are numerous and manifested in both private and social life as conflicts, disorganised families, commitment subcultural lifestyle. Social enviroment, education, science and culture are key means to develop individual and group social values and understanding of disturbing factors in social realty [4. P. 25], i.e. sociopathological problems can be the results of these elements' disfunctionality or of unsuccessful socialization. We are are not biopsychological creatures or isolated individuals, but a unit in interaction with other people, traditions, beliefs, values and moral norms that form the unconscious basis of our everyday life. Society is not an imaginary term for numerous deviant forms of behavior exist within it both determined by and affecting social enviroment.

The results of the research, or the indicators studied in the survey, point to structural social problems and identity crisis. Although the Republic of Srpska have some specific formal-legal features, social enviroment, education, science and culture are still basic elements that determine the dominant values of the society and the perception of disturbing factors in it. The results of the survey show that the society 
in general is aware of the meaning of most terms referring to paraphilia, but a kind of unawareness about less known forms of paraphilia does not mean that all these forms of deviant behavior are to be prevented on the institutional level - through education and legal sanctions. However, aggression seems to be a more preferable solution for the society tends to suppress forcibly interests, opinions, goals, values, and actions that are not traditional or socially acceptable by the majority.

In general, aggression is ubiquitous on the micro-level, conflicts and disagreements are determined by differences in personal motives, needs, interests, freedom and rights. Fights are typical for parents and children, between spouses and between parents and their parents, and there is a statistically significant connection between frequent family fights and phisycal violence. Alcohol addiction, drugs and gambling are most evident factors of violence against women. There is an acute need in the sociological study of violence and other sociopathological problems for most of them stay hidden in the private life and do not become public due to the suppressive social traditions that still prevail in many societies.

\section{REFERENCES}

[1] Aleksić J., Djorgović J. Priručnik za medijsko izvještavanje o nasilju u porodici i nasilju nad ženama [Handbook for the Media Coverage of Domestic Violence and Violence Against Women]. Beograd: Uprava za rodnu ravnopravnost, Ministarstvo rada i socijalne zaštite; 2011 (In Serbian).

[2] Bandura A. Teorija socijalnog učenja [Social Learning Theory]. Englewood Cliffs: Prentice Hall; 1977 (In Serbian).

[3] Bandura A., Ross D., Ross S.A. Prenos agresije putem imitacije agresivnih modela [Transmission of aggression through imitation of aggressive models]. Journal of Abnormal and Social Psychology. 1961: 63: 575-582 (In Serbian).

[4] Bošković M. Socijalna patologija [Social Pathology]. Novi Sad: Pravni fakultet; 2007 (In Serbian).

[5] Branković S. Metodologija društvenih istraživanja [Social Research Methodology]. Beograd: Zavod za udzbenike; 2014 (In Serbian).

[6] Bukelić J. Droga u školskoj klupi [Drugs in School Desk]. Beograd: Velarta; 2002 (In Serbian).

[7] Dragišić-Labaš S.Alkoholizam u porodici i porodica u alkoholizmu [Alcoholism in the Family, and Families in Alcoholism]. Beograd: Čigoja; 2012 (In Serbian).

[8] Dunn Jay I. Social and community psychiatry and individual social consciousness. Journal of Analytical Psychology. 1968: 13 (2): 146-154.

[9] Jakovljević V. Socijalna patologija [Social Pathology]. Beograd: Naučna knjiga; 1971 (In Serbian).

[10] Jugović A. Teorija društvene devijantnosti [Theory of Social Deviance]. Beograd: Partenon; 2013 (In Serbian).

[11] Kron L.J. Parafilije: definicija, etiologija, tipovi, klinički tretman i prognoze [Paraphilias: definition, etiology, types, clinical treatment and prognosis]. Zbornik Instituta za kriminološka i sociološka istraživanja. 2009: XXVIII (1-2): 117-127 (In Serbian).

[12] Ljubičić M. Porodica i delinkvencija [Family and Delinquency]. Beograd: Čigoja; 2011 (In Serbian).

[13] Merton R.K., Nisbet RA. Contemporary Social Problems. New York: Hartcourt Brace; 1971.

[14] Mihić I., Zotović M., Jerković I. Struktura i socijalno-demografska obilježja obiteljskog okruženja u Vojvodini [Structure and social-demographic characteristics of the family environment in Vojvodina]. Psihologija. 2009: 39 (2): 297-312 (In Serbian). 
[15] Milosavljević M. Devijacije i društvo [Deviations and Society]. Beograd: Draganic; 2003 (In Serbian).

[16] Rock P. Deviant Behaviour. London: Hutchinson University Library; 1973.

[17] Study of the Violence against Women in Bosnia and Herzegovina. Sarajevo: Agencija za ravnopravnost polova. http://bhas.ba/tematskibilteni/BHAS_Zene_Muskarci_BH.pdf.

DOI: 10.22363/2313-2272-2018-18-2-334-344

\title{
НАСИЛИЕ КАК ОСНОВНОЕ ПРОЯВЛЕНИЕ СОЦИАЛЬНЫХ ПРОБЛЕМ В БОСНИИ И ГЕРЦЕГОВИНЕ ${ }^{1}$
}

\author{
Б.Ч. Милошевич Шошо \\ Университет Восточного Сараево \\ Ул. Алексе Шантича, 1, Пале, 71000, Республика Сербская, Босния и Гериеговина \\ (e-mail: milosevic_biljana@yahoo.com)
}

Понятие «социальная проблема» было впервые использовано в научном дискурсе как синоним «социального заболевания», обусловленного неблагоприятными социально-экономическими условиями [9]. Сегодня социальные проблемы интересуют исследователей с точки зрения их негативных последствий для удовлетворения индивидуальных потребностей, в том числе в самореализации [15]. Согласно трактовке Р. Мертона и Р. Нисбета, социальные проблемы — «результат рассогласования между социальными ценностями и окружающей действительностью; следствие неблагоприятных социальных условий; они могут быть явными и латентными; они порождают социальные последствия и диктуют продуманные и осмысленные социальные действия» [10. Р. 156]. Автор рассматривает социальные проблемы в части Боснии и Герцеговины (БиГ) - Республике Сербской, стремясь способствовать их предотвращению и минимизации даже в самых социально-патологических формах. В период с октября 2016 по январь 2017 года было опрошено 220 респондентов (105 мужчин и 113 женщин) в семи муниципалитетах Республики Сербской. Автор оценивает осведомленность респондентов о значении разных форм патологического сексуального поведения (парафилиях) и уровень домашнего насилия, особенно в отношении женщин. Проект сочетал эмпирический и теоретический поиск, в частности разработку и проверку следующих гипотез: большинство респондентов не имеют представления о многих видах парафилии; женщины наиболее подвержены психологическому и физическому насилию вследствие меньших социально-экономических возможностей, и эта проблема почти не обсуждается в обществе вследствие устойчивости традиционных коммуникативных и социальных барьеров. Для подтверждения этих гипотез автор оценивает взаимосвязь разных переменных опроса и показывает, какие факторы влияют на названные социальные проблемы. Их дальнейшее замалчивание способствует развитию девиантных (и деликвентных) форм поведения, которые становятся социально приемлемыми и негативно влияют на общество.

Ключевые слова: социальная проблема; насилие; парафилия; домашнее насилие; опрос; Республика Сербская.

* ( С Милошевич Шошо Б.Ч., 2018. 